\title{
Employment trajectories in Germany: do firm characteristics and regional disparities matter?
}

\author{
Matthias Dütsch • Olaf Struck
}

Published online: 29 January 2014

(C) Institut für Arbeitsmarkt- und Berufsforschung 2014

\begin{abstract}
Life course research accentuates that employment trajectories are governed by individual determinants and endogenous causalities; thus, the start to the employment career enduringly affects workers' future mobility patterns. However, their actions are always embedded within a particular framework: Their employment trajectories are influenced by firm-specific opportunity structures, regional heterogeneities, and the business cycle. This article focuses on the structural factors framing worker's mobility processes.
\end{abstract}

Structural and cyclical determinants were assessed by combining a German linked employer-employee dataset with data on regional economic characteristics from the statistical "spatial planning regions". The hierarchically clustered data were explored with multilevel analysis models. These identified the key factors influencing employment stability; the determinants of upward, lateral, and downward interfirm mobility; and transitions leading to unemployment.

Our results show that employees can minimize the endogenous causality by taking advantage of particular framework conditions: A firm's investments in further training and internal infrastructure impact positively on employment trajectories, and work councils increase employment stability, especially during periods of economic growth. In contrast, employment trajectories are destabilized by disadvantageous firm demographics and intensive use of fixed-term employment. During an economic downswing, employment opportunities are better in densely populated areas, whereas

M. Dütsch ( $\varangle)$ · Prof. Dr. O. Struck

Chair of Labour Studies, Otto-Friedrich University of Bamberg, Feldkirchenstraße 21, 96052 Bamberg, Germany

e-mail: matthias.duetsch@uni-bamberg.de

url: http://www.uni-bamberg.de/arbeitswiss unemployment risks dominate in rural areas. In the period of economic growth, all employees within a region benefit from a higher local level of human capital regardless of qualification level, whereas during an economic downturn, skill segregation prevails and only the highly qualified benefit.

Keywords Job duration - Employment career - Structural effects $\cdot$ Linked employer-employee data

JEL Classification J62 · J64 · M51 · O15

\section{Erwerbsverläufe in Deutschland: Zur Bedeutung betrieblicher Charakteristika und regionaler Disparitäten}

Zusammenfassung Die Lebensverlaufsforschung betont die Bedeutung individueller Faktoren sowie des endogenen Kausalzusammenhangs für den Erwerbsverlauf. Demnach bestimmt insbesondere der Einstieg in die Erwerbsphase zukünftige Chancen und Risiken im Erwerbsleben. Allerdings ist zu berücksichtigen, dass Arbeitskräfte innerhalb spezifischer Rahmenbedingungen agieren. So werden deren Erwerbsverläufe durch betriebliche Gelegenheitsstrukturen geprägt. Zudem handeln Arbeitnehmer und Arbeitgeber in unterschiedlich strukturierten Regionen. Schließlich sind auch konjunkturelle Einflüsse zu beachten. Deshalb richtet der vorliegende Artikel den Fokus auf die Untersuchung struktureller Einflussfaktoren.

Um strukturelle und konjunkturelle Determinanten abbilden zu können, wurde ein Linked Employer-Employee Datensatz des IAB und Daten zu regionalen Charakteristika auf Ebene der Raumordnungsregionen verknüpft. Die Auswertung der hierarchisch geclusterten Daten wurde anhand von Mehrebenenmodellen durchgeführt. Zunächst wurden 
die Einflussfaktoren auf die Beschäftigungsstabilität und danach die Determinanten von Aufstiegen, lateraler Mobilität und Abstiegen bei direkten Betriebswechseln sowie von Übergängen in Arbeitslosigkeit erforscht.

Unsere Ergebnisse zeigen, dass die zweifellos vorhandenen endogenen Kausalzusammenhänge im Erwerbsverlauf dann an Bedeutung verlieren, wenn Beschäftigte sich strukturelle Einflussfaktoren zunutze machen können: Demnach wirken betriebliche Investitionstätigkeiten in Weiterbildung sowie in die Infrastruktur positiv auf Erwerbsverläufe. Betriebsräte und Personalvertretungen erhöhen vor allem in einer guten konjunkturellen Situation die Beschäftigungsstabilität. Hingegen können eine ungünstige Organisationsdemografie sowie die intensive Nutzung von Befristungen zur Destabilisierung des Erwerbsverlaufs führen. In einer konjunkturellen Abschwungphase bieten dichter besiedelte Räume bessere Beschäftigungsoptionen, während in ländlichen Gegenden Beschäftigungs- und Arbeitslosigkeitsrisiken herrschen. Von einer hohen regionalen Humankapitalausstattung profitieren im Aufschwung alle Qualifikationsgruppen, während im Abschwung eine Segregation bezüglich der Qualifikationsgruppen zu beobachten ist.

\section{Introduction}

The employment period is a decisive phase in the life course. It strongly influences opportunities in life, especially with regard to wage levels and welfare state entitlements (Heinz 2006; Vobruba 2000). As a result, job stability has a high value from the worker's perspective. It shelters from the risk of unemployment and allows the development of human capital (Blossfeld et al. 2006; Boockmann and Steffes 2010; Winkelmann and Zimmermann 1998). However, recent studies have concluded that the German labor market is characterized by a significant and growing proportion of mobile workers (Blossfeld et al. 2006; Giesecke and Heisig 2011). Despite this change, modern approaches to understanding employment systems show that job stability can also be assured in open employment systems when there are adequate opportunities for interfirm mobility (Alewell and Hansen 2012; Lepak et al. 2006; Struck and Dütsch 2012). These allow workers to both preserve and further develop their occupational skills throughout their employment careers. However, downward mobility or transitions to unemployment cause a loss of qualifications and lead to unfavorable labor market chances in the future (ebd.).

To date, most research has focused on the individual determinants influencing employment trajectories. The important role of factors such as gender, nationality, educational level, and the particular age cohort in explaining employment (dis-)continuities has been widely documented
(Bergemann and Mertens 2004; Giesecke and Heisig 2011; Hillmert et al. 2004). Furthermore, it is accentuated that employment trajectories are governed by endogenous causality; cohort analyses indicate that a poor start to the employment career may impact negatively on future mobility patterns (Blossfeld 1986; Hillmert et al. 2004).

Although Coleman (1990) has pointed to the importance of the broader social context for individual behavior, research on labor mobility has paid less attention to structural effects. Thus, the impact of firm-specific factors and regional disparities on employment trajectories has remained largely unexplored. Because "new structuralism" stresses the significance of accounting for firm characteristics (Baron and Bielby 1980), it seems pertinent to consider these factors further. Moreover, spatial economics, especially the seminal theory on "new economic geography" (Krugman 1991), has triggered a wave of empirical work on spatial analysis. Using this theoretical approach, several economists have shown the relevance of regional factors for the development of both employment and wages in Germany (Blien 2001; Blien et al. 2001; Möller and Tassinopoulos 2000).

This article seeks to contribute more fully to research on employment trajectories by focusing on three structural framework conditions in greater detail. These are (1) whether and to what extent job exits as well as upward, lateral, or downward interfirm mobility and transitions into unemployment are influenced by firm-specific characteristics; and (2) whether and to what extent these mobility processes correlate with various regional determinants. Additionally (3) different economic conditions will be taken into account to analyze their impact on labor mobility. Thereby, it should be studied if employees can minimize the significant effect of individual determinants and endogenous causalities, which are stated by life course researchers, by taking advantage of particular framework conditions. The article studies these conditions by combining a German linked employer-employee dataset with data on regional characteristics from the Federal Institute for Research on Building, Urban Affairs and Spatial Development (BBSR). Based on this hierarchically structured dataset, it deploys a multilevel framework to evaluate the different mobility processes. The article starts by reviewing the current state of research in Sect. 2. Theoretical considerations are presented in Sect. 3. Data and the estimation strategy are described in Sect. 4. Section 5 contains the empirical results on employment careers in Germany. Finally, Sect. 6 summarizes the findings.

\section{Current state of research}

Several recent empirical studies have demonstrated a range of effects of firm characteristics on employment careers. 
Grotheer et al. (2004) looked at the job stability of employees who had just joined a firm. They found a stabilizing effect of work councils on employment as well as a strong correlation between the prevalence of part-time or fixedterm employment and employees leaving the firm. A lack of opportunities for promotion owing to a firm's age demographics was shown to have only a slightly positive effect on the probability of leaving a firm. According to Boockmann and Steffes $(2005,2010)$, a positive effect was evident from those firms that provided opportunities for further education. Work councils decreased job exit rates especially for blue-collar workers. Bergemann and Mertens (2004) found higher risks of dismissals in smaller firms along with lower rates of layoffs and voluntary departures in larger firms. Moreover, Giesecke and Heisig (2011) showed that men working in larger firms are much more likely to change employer.

Only a few studies have assessed the effect of regional indicators on job stability or employment trajectories. According to Grotheer et al. (2004), fluctuations in production and demand as well as high regional unemployment rates provoke a change of employer in western Germany, whereas mobility between firms and exits into unemployment are lower in eastern Germany. Boockmann and Steffes (2005) have reported similar results on unemployment rates within each German state. Whereas in western Germany, they could observe no definite link between higher rates of unemployment and job stability, the former proved to have a stabilizing effect in eastern Germany. Furthermore, a higher unemployment rate increases the risk of being made redundant after completing tenure of employment in western Germany. In eastern Germany, interfirm changes are less probable for women. However, in a further study of male employees, Boockmann and Steffes (2010) failed to find a significant impact of higher unemployment rates on job stability, but that it did lead to a decrease in mobility between western German firms.

Some current research shows the effect of the economic cycle on employment careers. Erlinghagen (2005) found an increased probability of involuntary dismissal during periods of economic decline in western Germany between 1985 and 2001. According to Giesecke and Heisig (2011), the probability of changing job increases during periods of economic growth. Struck et al. (2007) found more voluntary fluctuation in periods of growth and higher levels of stability among long-term employees. Hübler and Walter (2009) identified a contracyclical risk of dismissal as well as a procyclical risk of terminating employment. Although macrolevel studies cannot fully explain the reasons for these employment dynamics, they do support the assertion that job changes occur in a procyclical environment (Fitzenberger and Garloff 2007; Schaffner 2011). International studies indicate that wages are also subject to procyclical fluctuations: They fall in periods of economic decline for both existing staff and new entrants (Devereux and Hart 2006; Hart 2006).

To summarize, the literature reveals that several empirical studies have focused on firm characteristics and economic conditions and their impact on employment stability as well as the probability of becoming unemployed. However, there has been insufficient research on interfirm mobility processes. Regional heterogeneities-with the exception of East-West comparisons-are mostly neglected in research on employment trajectories, even though macrolevel studies point to considerable effects of regional disparities on employment and wages. Bearing this in mind, the following analysis of mobility processes aims to close these identified research gaps. It examines the impact of firmspecific and regional determinants as well as economic conditions on job exits; on upward, lateral, or downward interfirm mobility rates; and on transitions into unemployment. The next section presents the theoretical background and formulates the hypotheses to be tested in the empirical analyses.

\section{Theoretical background}

\subsection{Firm-specific factors and the career path}

Recent life-course research has studied the effect of internal firm processes and structures on individual career opportunities, wages, and socioeconomic status (Ahrne 1994; Baron and Bielby 1980; Struck 2006). Employment careers and mobility processes are perceived as the outcome of an interaction between employers and employees. The dynamics of this interaction stem from the labor market segmentation practiced by firms within the framework of the institutional setting (Doeringer and Piore 1971; Sengenberger 1987). With this in mind, recent approaches in human resource management systems (HRMS) as well as employment systems derive segmentation processes from a firm's internal labor and employment organization (Hendry 2003; Lepak et al. 2006; Struck and Dütsch 2012). They argue that firms are made up of and apply different employment systems that vary in the average duration of the employment relationship and the opportunities for mobility. Therefore, openness to external markets depends on the internal labor organization, the technical equipment, and the demand for professionally accredited qualifications. However, it also depends on the availability of workers within both internal and external labor markets (ibid.).

In this context, vacancy chain models explain internal employment trajectories by supposing that employment sys- 
tems are characterized by either more open or more closed positioning systems (Sørensen 1977). When an employment system is relatively closed due to institutional arrangements such as collective agreements, vacancies normally arise through voluntary departures from the firm. In this situation, the worker occupying the next lower position in the hierarchy will be promoted to the vacant position (ibid.). Approaches in organizational demography extend this vacancy chain model to account for the impact of a firm's demographic structures on internal career options (Mittman 1992; Pfeffer 1985). Thus, the age distribution of the workforce can block promotion opportunities for employees positioned ahead of a large age cohort. This creates an employment environment that may encourage voluntary interfirm mobility. This leads to the following hypotheses:

H1: The probability of workers leaving their employers will increase when internal promotion opportunities are blocked.

$\mathrm{H} 2$ : Because the mobility processes triggered by blocked promotion opportunities are voluntary, they will result in lateral or upward interfirm job changes.

Regarding firm size, it is often thought that smaller firms show a higher rate of staff turnover than larger ones due to their more limited capacity to adapt to changing market conditions. Larger firms are in a better position to cope with, for example, sudden fluctuations in sales revenue, because they can balance out lost sales in one product area through gains in another (Struck 2006). Furthermore, they can offer more employment opportunities and promotion prospects. Hence, larger firms are characterized as being able not only to offer more possibilities for changing jobs, both laterally and vertically, but also to retain more staff than smaller firms (Baron and Bielby 1980; Carroll and Mayer 1986). This leads to two further hypotheses:

\section{H3: The larger a firm, the higher its job stability.}

$\mathrm{H} 4$ : Interfirm job changes following employment in a larger firm will be mostly voluntary and therefore lead more frequently to lateral or even upward mobility.

Owing to processes of economic transnationalism (Blossfeld et al. 2006; Giesecke and Heisig 2011) and the shifting of sociostructural frameworks (Struck 2006), firms are increasingly taking advantage of instable and fixed-term employment relationships in order to remain competitive by exploiting the potential of flexibility. In line with segmentation theory, these atypical types of employment are assigned to a firm's noncore workforce (Doeringer and Piore 1971; Sengenberger 1987). It is assumed that both job mobility rates are high and human capital cannot be embedded or maintained within the noncore workforce (Blossfeld et al. 2005; Struck and Dütsch 2012). Moreover, fixed-term em- ployment is often attributed to the noncore area, because employers can circumvent the relatively strict employment protection regulations and minimize transaction costs when laying workers off (Hohendanner 2010). Fixed-term employees therefore face a risk of receiving less stable jobs. As a result, when there is a large share of fixed-term employees, a firm's employment system is considered to be more open (ibid.; Struck and Dütsch 2012). This leads to the next hypothesis:

H5: The higher the fixed-term share of a firm's workforce, the lower the job stability.

The heightened structural and demographic changes have engendered an extensive discussion on the past and future role of education as well as on the acquisition of competencies (Büchel and Pannenberg 2004; Dieckhoff 2007). Lifelong learning and the completion of further training are considered to be highly important if individuals are to possess up-to-date knowledge and maintain or improve their social status. Moreover, further training programs are considered to be highly relevant if firms are to stay competitive, because they ensure a constant adaption of their employees to modern technologies and work processes (ibid.). This is in keeping with human capital theory that emphasizes the importance of education and training in raising the productivity of workers by increasing their cognitive abilities and their individual capability (Becker 1962). However, there is no guarantee that workers receiving further training will remain in a firm. Therefore, employers try to reduce voluntary quits and avoid "sunk costs" (Neubäumer 2006) by paying higher wages and offering promotion opportunities (Büchel and Pannenberg 2004; Dieckhoff 2007). Furthermore, it is assumed that firms providing further training are regarded as good opportunity structures by both their own staff and external third parties. This indicates a higher reputation compared to firms that do not offer further training. Employees may profit from a firm's high reputation, because their own individual reputation is also enhanced by the reputation of the group or organization they belong to (BackesGellner and Tuor 2010; Tirole 1996). Hence, a firm's good reputation is considered to be a positive signal that is also ascribed to the current staff. Workers leaving such a firm may therefore achieve lateral or upward interfirm mobility either because of their gain in productivity due to the further training they have received or because of the ascribed positive signal. This results in the next two hypotheses:

H6: Those firms that offer further training opportunities will provide more stable jobs.

H7: Workers leaving firms that offer further training programs will be able to achieve interfirm job change and avoid downward mobility. 
Investment in modern technologies often requires specific human capital and specific training (Bresnahan et al. 2002). Workers employed in firms working with the latest technology should be able to accumulate human capital that is more specific and up to date than those working in firms using outdated technology. However, modern machinery and equipment may increase not only workers' productivity but also the employer's efforts to prevent voluntary quits (Neubäumer 2006). Job stability is therefore assumed to be high in such firms (Boockmann and Steffes 2010). Furthermore, modern firms can be viewed as good opportunity structures that, in turn, suggest a comparatively favorable reputation. Employees may therefore benefit from a firm's modern technologies by being ascribed positive signals and gaining the opportunity to quickly find another employer. The hypotheses are as follows:

H8: A high level of technological development will increase job stability in a firm.

H9: Employees who have worked in modern firms will be able to manage immediate transitions between firms.

Work councils are regarded as an instrument for disciplining employers who take an opportunistic approach to employment, information, or payment (Jirjahn 2009; Mohrenweiser et al. 2012). Especially when employers break nonenforceable and, therefore, implicit contracts about particular working conditions by announcing, for example, lay-offs, employee representation is deemed to promote industrial democracy through its legal co-determination rights (ibid.). Based on their veto rights as well as participation and consultation rights, work councils are able to increase employees' bargaining power. Because they can delay decisions, work councils may increase an employer's transaction costs. Moreover, worker co-determination increases employees' work satisfaction resulting in fewer voluntary quits (Pfeifer 2011). For this reasons, it is hypothesized:

H10: The presence of work councils and employee representatives will ensure the closure of internal employment systems and thereby increase employment stability.

\subsection{Region-specific factors and the career path}

What several established labor market theories have in common is a tendency to avoid addressing and explaining the role of macrostructural factors on the labor market (Fujita et al. 2001). In contrast, research on regional economics, which has become increasingly significant within economic science in recent years (ibid.; Krugman 1991, 1998), focuses on explaining regional heterogeneities and their effects on regional growth. Krugman (1991) has developed a coreperiphery model based on the work of Hirschman (1958) that considers a range of divergent centripetal and centrifugal forces. It looks at the effect of positive external factors and points to the mutual relationship between economies of scale, transportation costs, and migration. Thus, centripetal forces lead to urbanization effects because they encourage the concentration of economic activities within a certain geographical area. Industrial centers are strengthened because firms and employees capitalize agglomeration advantages. In the case of high economies of scale, a company tries to limit production to one single facility and to serve the market from there. In order to reduce transportation costs, the company will set up in a location with a high population density and, therefore, higher demand. Both the workforce and firms are attracted to a regional economy in order to realize the agglomeration advantages given by a larger potential sales market and employee pool (Krugman 1991). Hence, lower transportation costs and higher economies of scale increase the likelihood of development for economic centers and peripheries alike.

According to Fassmann and Meusburger (1997), a primary segment of the labor market, characterized by stable jobs, good wages, promotion prospects, and a predominance of more highly qualified employees, will be found in central or core economic locations. This is dependent on stable levels of demand and higher economies of scale. Furthermore, lateral or even upward interfirm mobility is higher in denser regions, because the same location is shared by several other competitors and potential employers. In contrast, a secondary segment of the labor market characterized by instable and badly paid jobs, lower qualifications, marginal promotion prospects, and high unemployment will take root in rural areas. This is due to poor market efficiency, instable levels of demand, and the fact that other potential employers are located far away. The following hypotheses are proposed:

H11: Employees who work in core areas will benefit from agglomeration advantages through high job stability.

H12: In denser regions, lateral and upward interfirm mobility will take place to a greater extent.

H13: Job stability will be lower and unemployment risks will be higher in rural areas.

A further approach to regional research-endogenous growth theory-has established a link between the qualification structures of a regional workforce and economic development. It contests the assumption of neoclassical labor market theory that long-term economic growth is determined exogenously (Lucas 1988). Instead, it emphasizes the dependence of regional economic growth potential on the level of skills and knowledge available in the region. Because employees' productivity increases alongside the acquisition of human capital, the strength of locally embedded human capital is considered to be the "engine of growth" 
(Lucas 1988) over and above any technological progress. In this theory, all groups of workers and firms in a region might benefit from productivity gains. According to Lucas (1988), this is a result of positive external effects caused particularly by productivity gains within certain groups of workers (e.g., the highly skilled). These spillover effects may be due to, for example, signaling effects and/or the supply chain. Blien and Wolf (2002) as well as Farhauer and Granato (2006) have confirmed this assumption. In contrast, however, other studies have shown a divergent development in terms of employment and wages: In line with the thesis of skill segregation, especially highly qualified employees are seen to profit from an improvement in the regional skill-level structure (Gerlach et al. 2002; Schlitte et al. 2010; Stephan 2001). The following hypotheses are derived:

H14: The higher the local level of human capital, the more stable employment will be for all workers. This stability may be realized internally or through lateral or upward interfirm mobility.

H15: A high local level of human capital results in skill segregation. As a result, the jobs of lower skilled employees will be less stable, whereas the highly skilled will profit through stable jobs or even upward interfirm mobility.

\subsection{Career paths and the business cycle}

The effects of cyclical fluctuations on employee mobility in the labor market can be illustrated with the sorting model. This explains labor market fluctuations and the efficient reallocation of employees to workplaces (Hinz and Abraham 2008; Struck 2006). It posits that seeking new employment while in work will result in a change of job only if it holds the promise of higher wages or other nonmonetary benefits as well as compensation for the extra expenses incurred through job seeking. Therefore, this model provides an economic indicator of employee behavior in terms of the decision to terminate an employment contract. Assuming that a period of economic growth leads to the generation of better paid jobs, then not only will interfirm mobility rise due to voluntary job transitions but also, parallel to this, average job stability will decline. On the other hand, during a recession, only a few attractive jobs will be generated and there will be hardly any margin for wage increases. Thus, the incentive for voluntary mobility declines, whereas involuntary layoffs and unemployment risks rise (ebd.). This produces the following hypothesis:

H16: An economic upswing will lead to upward interfirm mobility; in contrast, a cyclical downturn will trigger transitions into nonemployment.

The next section describes the data and the estimation strategy used to test the hypotheses.

\section{Data and method}

\subsection{Data and sample definition}

The database for the following empirical analyses is the German LIAB, a linked employer-employee dataset from the "Institute for Employment Research" (Jacobebbinghaus 2008). It combines data on employees with the "IAB Establishment Panel", which is a representative annual survey of 16,000 business establishments (Fischer et al. 2008). This study uses the "LIAB longitudinal version 2", which includes approximately 9,700 firms that took part in the survey continuously between either 1999 and 2001 or 2000 and 2002. The employment and welfare recipient histories for the period from 1993 to 2006 were drawn from those persons who were employed in any of the LIAB firms for at least one day between 1997 and 2003.

Data on employees is taken from two different sources. First, the "employee history" contains data on individual employment history records submitted by employers to the German public pension insurance system. The reliability of this data is high, because failure to supply accurate information is a legal misdemeanor that may even result in a summary offense. One exception is individual information on the education variable that is adjusted by imputation (Fitzenberger et al. 2005). The employment statistics register covers about $80 \%$ of total employment. Moreover, the "benefit recipient history" contains data on the receipt of unemployment benefits, unemployment assistance, or maintenance allowance. Basic personal data on individual employment histories is left-censored and can thus be tracked from January 1, 1993 onward. The generated data enables us to identify the three labor market states "unemployment", "new employment", and "employment gap" However, it is not easy to identify all periods of unemployment because information is recorded only for the periods in which a person receives unemployment benefits from the German Federal Employment Agency. As a result, the data do not account for those unemployed people who were not officially registered as such. Thus, a cleansing procedure is used to generate the three labor market states detailed above. A job change between firms is defined as a period of unemployment not exceeding 90 days. It is likely that in most of these cases, workers already knew their new employers when the previous job ended. An unemployment period is defined, moreover, as a period in which the job seeker receives unemployment benefits for at least one day within a 90-day period. Finally, the state "employment gap" is activated when no change of employment has occurred nor have unemployment benefits been received within the 90-day period. Thus, this data allows us to construct complete employment biographies for those employees covered by the LIAB. 


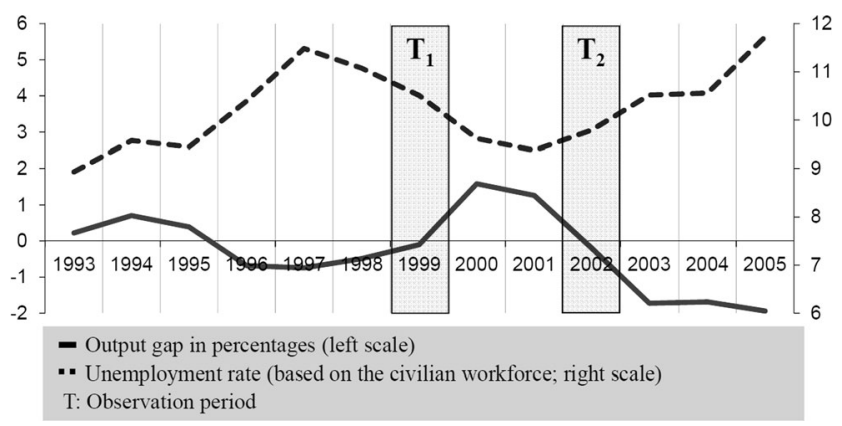

Fig. 1 Observation periods and the economic cycle

In addition, the LIAB dataset is merged with data on regional characteristics derived from the Federal Institute for Research on Building, Urban Affairs and Spatial Development (BBSR). This contains information on rates of unemployment, GDP per capita, regional typologies with regard to population density, and their place as core or peripheral regions, as well as the share of students. This data is based on annual averages. The identified indicators exist for the 97 German spatial planning regions, and this is considered adequate for analyzing regional labor markets (Rendtel and Schwarze 1996; Schwarze 1995). Thus, this generated dataset permits simultaneous analyses of employers, employees, and the regional context. As noted in Sect. 3.3, it is necessary to account for cyclical effects on employment trajectories. Therefore, terminations of employment in 1999 and 2002 were examined. As Fig. 1 shows, using the output gap ${ }^{1}$ as well as the unemployment rate, 1999 was characterized by economic growth; 2002, by decline (cf. also Sachverständigenrat 2008, 2009).

The period covered in $\mathrm{T}_{1}$ examines persons who were already employed on January 1, 1999 or were employed between January 1, 1999 and December 31, 1999. $\mathrm{T}_{2}$, on the other hand, covers employees who were part of the workforce as of January 1, 2002 or were employed between January 1, 2002 and December 31, 2002.

The data used here is restricted to full-time employees aged $25-52$ years. Thus, individuals in vocational training or students working during the university break are excluded. This also helps to avoid any confusion between those exiting employment and those taking early retirement. Furthermore, employees whose income is above the income assessment ceiling are excluded because this information is censored. These conditions provide a sample of 370,779 persons, 1,836 firms, and 97 regions during 1999 along with 363,339 workers, 2,140 firms, and 97 regions during 2002.

\footnotetext{
${ }^{1}$ The definition proposed by the expert advisory board is used to date distinct cyclical up- and downswing phases. The concept of the expert advisory board (Sachverständigenrat 2008: 78ff.) reflects the so-called output gap, that is, the relative deviance of the GDP from the production potential given as a percentage.
}

\subsection{Econometric method}

In the following, multivariate analyses are performed using data covering workers, firms, and regions. This structuring of the data from the level of workers to regions is an important aspect when choosing an estimation procedure. Moulton $(1986,1990)$ has noted that the inclusion of mesoand macrolevel variables in a standard regression analysis in which observations are assumed to be independent leads to an inefficient estimation of the coefficients and to biased standard errors. Therefore, multilevel models are preferable, because they allow a grouping of individuals $i$ within firms $j$ nested in regions $k$ by considering residuals at the firm and the regional level. These residuals represent unobserved characteristics that cause correlations between outcomes for employees from the same firm and region.

The empirical analyses are performed with the following three-level logistic random intercept model (Rabe-Hesketh and Skrondal 2008; Skrondal and Rabe-Hesketh 2003):

$$
\begin{gathered}
\operatorname{logit}\left\{\operatorname{Pr}\left(y_{i j k}=1 \mid x_{i j k}, C_{j k}^{(2)}, C_{k}^{(3)}\right)\right\} \\
=\beta_{0}+\beta_{1} x_{i j k}+C_{j k}^{(2)}, C_{k}^{(3)}
\end{gathered}
$$

in which $\beta_{0}$ represents the regression constant, $\beta_{1}$ refers to the regression coefficients, and $x_{i j k}$ is a vector with explanatory variables at the individual, firm, and regional levels. Finally, $C_{j k}^{(2)}$ and $C_{k}^{(3)}$ denote the random effects that are assumed to be independent not only of each other but also across clusters. $C_{j k}^{(2)}$ is also assumed to be independent across units. Based on this three-level approach, employment trajectories are assessed using a two-stage procedure: First, we estimate the risk of job exit; second, we use four further three-level logistic random intercept models to explore the following destination states: "upward job-tojob mobility" (defined as an increase in wages of at least $10 \%$ ), "lateral job-to-job mobility", "downward job-to-job mobility" (defined as a decrease in wages of more than $5 \%$ ), and "unemployment". ${ }^{2}$ All dependent variables are coded as dummy variables. In the first step, the value 1 represents a job exit; it takes the value 0 , when the employee remains in the firm. In the second step, the value 1 respectively denotes one of the destination states; the value 0 subsumes all other employment states in each case. ${ }^{3}$

\footnotetext{
${ }^{2}$ We use asymmetric boundaries for upward and downward mobility, because we assume that employees perceive even slight reductions in wages as a worsening of their situation. In contrast, workers may perceive slight increases in wages as being normal and matching inflation. Therefore, the boundary for upward mobility is higher than that for downward mobility. The exit state "employment gap" is not reported for purposes of clarity. These results are available from the authors on request.

${ }^{3}$ Some descriptive statistics on the dependent variables are reported in Table 4 in the Appendix.
} 
Table 1 Status after leaving employment

\begin{tabular}{|c|c|c|c|c|c|}
\hline & \multicolumn{2}{|l|}{1999} & \multicolumn{2}{|l|}{2002} & \multirow[t]{2}{*}{$p$ value } \\
\hline & $\%^{b}$ & $n$ & $\%^{\mathrm{b}}$ & $n$ & \\
\hline Exit from job ${ }^{c}$ & 9.16 & 33,949 & 8.34 & 30,286 & 0.371 \\
\hline Exit states & & & & & 0.000 \\
\hline Interfirm upward mobility & 20.04 & 6,803 & 13.73 & 4,159 & \\
\hline Interfirm lateral mobility & 15.05 & 5,111 & 14.07 & 4,262 & \\
\hline Interfirm downward mobility & 9.88 & 3,355 & 9.61 & 2,911 & \\
\hline Unemployment & 25.98 & 8,820 & 29.88 & 9,049 & \\
\hline Employment gap & 29.04 & 9,860 & 32.70 & 9,905 & \\
\hline
\end{tabular}

${ }^{a}$ t-tests and chi-square tests were performed to explore the differences between the two years

bercentages do not add up to exactly 100 due to imprecise rounding

${ }^{\mathrm{c}}$ The total number of observations was 370,779 in 1999 and 363,339 in 2002

Source: Linked Employer-Employee Data (LIAB); own calculations

This analysis is carried out using a large set of 50 explanatory variables that can be divided into those concerning individual, firm-specific, and region-specific factors. Looking at individual factors, information includes details on gender, age, level of education, nationality, job position, as well as on the corresponding firm entrance cohorts and on previous periods of employment. Firm-specific characteristics include firm size, age distribution, details on contracts and investments, the presence or absence of work councils, and the employment sector. Region-specific factors concern the differentiated types of regions, the level of human capital, productivity, and the unemployment rate. ${ }^{4}$

\section{Results}

\subsection{Transition patterns after leaving employment}

First, descriptive transition rates of the full-time employed are examined for the years 1999 and 2002 in order to obtain an indication of mobility patterns during different economic and business cycles. These are illustrated in Table 1 .

Results show that in the majority of cases, irrespective of the economic environment and in both years, almost $10 \%$ of employees left their firm. Approximately $20 \%$ of workers attained a higher position through interfirm mobility in 1999, a period of economic growth, whereas $55 \%$ were not in employment. During the periods of economic decline, only $14 \%$ of employees im-

\footnotetext{
${ }^{4}$ Descriptive statistics of individual, firm-specific, and region-specific characteristics are reported in Tables 5 to 7 in the Appendix.
}

proved their employment status through interfirm mobility. In contrast, $63 \%$ moved into nonemployment. These varying patterns of mobility corroborate Hypothesis 16 . On the whole, results are in line with the procyclical fluctuations in employment mobility (Fitzenberger and Garloff 2007; Hübler and Walter 2009; Schaffner 2011) and procyclical wage increases (Devereux and Hart 2006; Hart 2006) found in other research.

\subsection{Examination of the variance components}

Three-level logistic random intercept models are estimated to analyze the several destination states. ${ }^{5}$ In models without explanatory variables (intercept-only models), the variance in the outcome variable can be decomposed into proportions associated with the individual level, the firm level, and the region level. For this purpose, the random part of the threelevel models is explored by considering the estimated residual intraclass correlation $\rho$ for the latent responses. It is assumed that the level- 1 error variance is equal to $\pi^{2} / 3$ for the logistic link function (see, e.g., Rabe-Hesketh and Skrondal 2008). Then we can obtain for the similarity of employees $i$ within the same region $k$ :

$\rho($ region $)=\frac{\psi^{(3)}}{\psi^{(2)}+\psi^{(3)}+\pi^{2} / 3}$.

Within the same firm $j$ (and the same region $k$ ), we get:

$\rho($ firm, region $)=\frac{\psi^{(2)}+\psi^{(3)}}{\psi^{(2)}+\psi^{(3)}+\pi^{2} / 3}$.

The intercept-only analyses show that the values of $\rho$ (firm, region) vary between 0.202 and 0.416 in 1999 and between 0.325 and 0.482 in 2002 for the observed exit states; those of $\rho$ (region) range between 0.010 and 0.011 in 1999 as well as in $2002 .{ }^{6}$ These findings indicate, on the one hand, that most of the variation can be ascribed to employees; on the other hand, that significantly more variation is attributable to firms rather than to regions.

The next section addresses which firm and regional factors influence the opportunities and risks in employment careers in the two different cyclical phases by estimating three-level logistic random intercept models with explanatory variables. These results are illustrated in Table 2. Although all of the explanatory variables are reported, we interpret only those that are relevant for testing the hypotheses.

\footnotetext{
${ }^{5}$ All estimations were performed using the lmer function from the lme 4 package of the statistical software R. This was very time consuming, because it took 30 days to get the results.

${ }^{6}$ The complete estimates are given in Table 8 in the Appendix.
} 


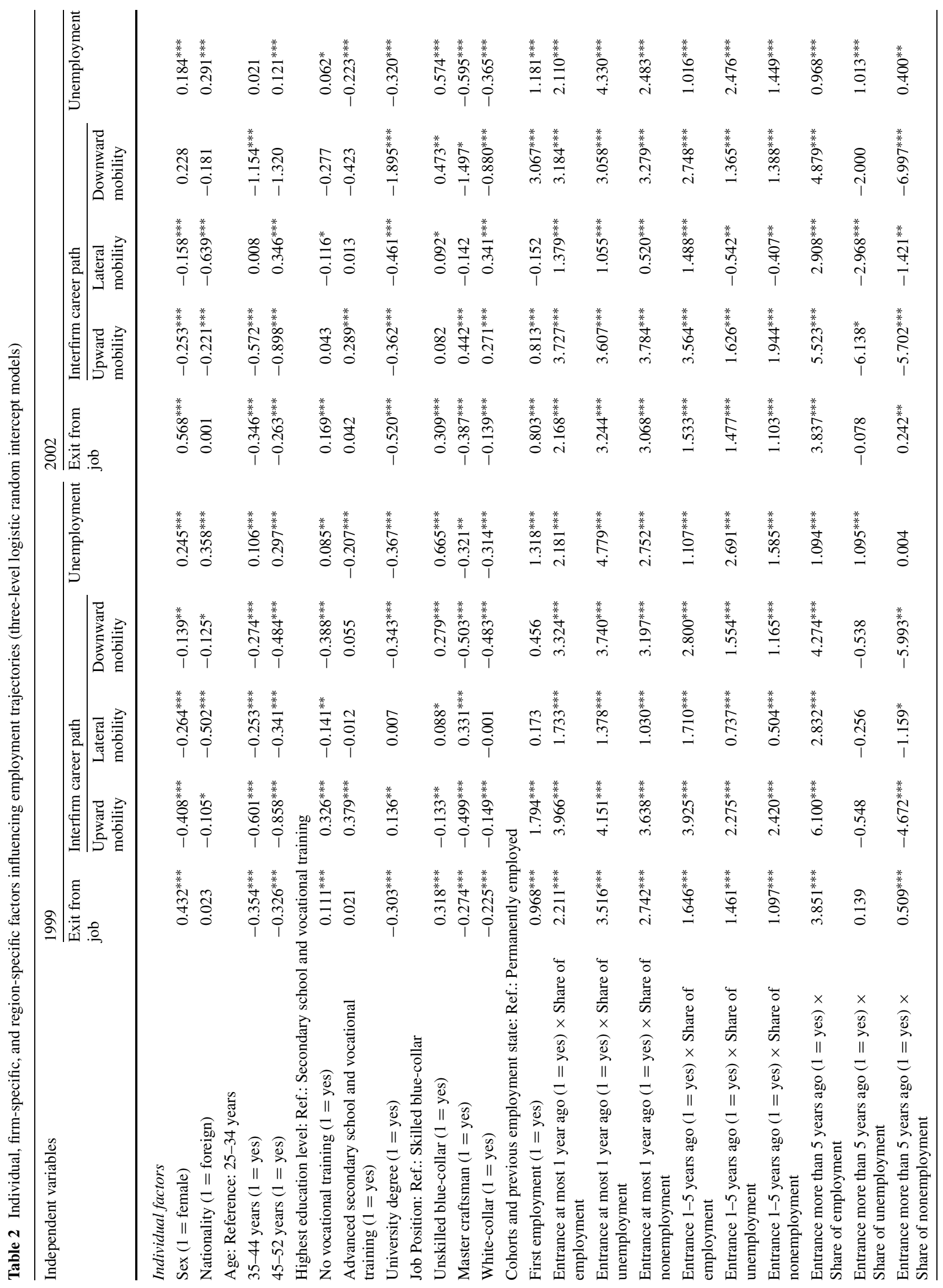




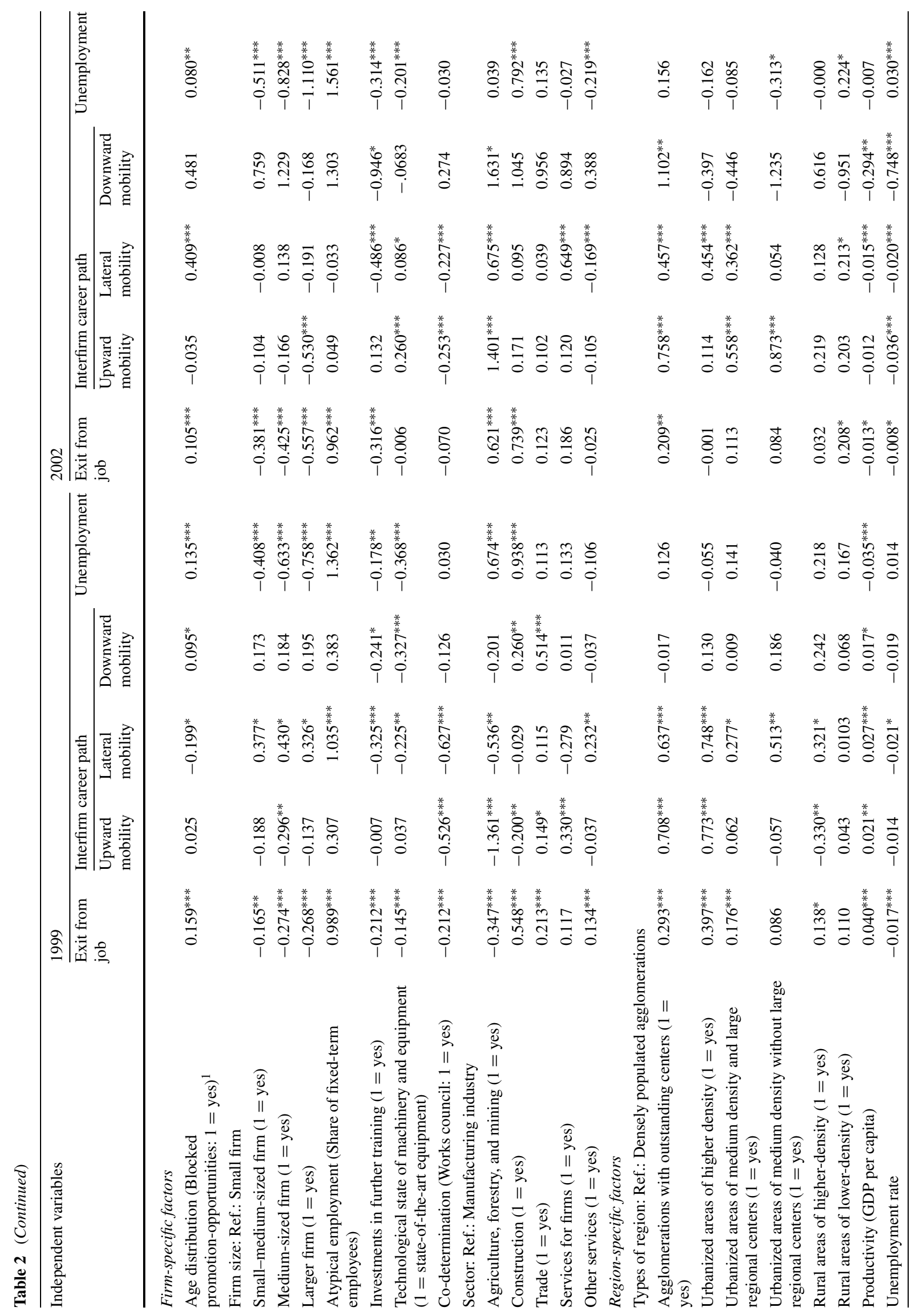




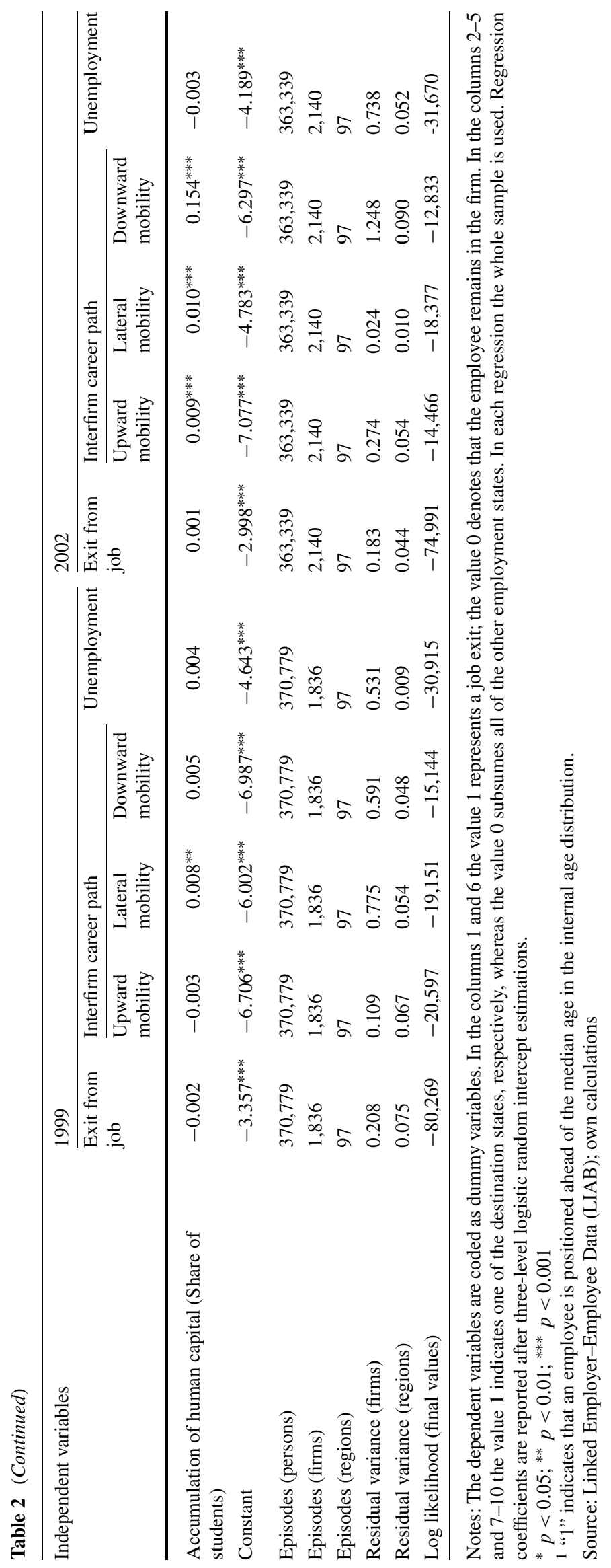




\subsection{Firm-specific determinants}

It has been stated that internal career progression is influenced by a firm's demographics. Results show that it is actually those workers positioned ahead of a large age cohort who are most likely to leave their firm. ${ }^{7}$ This is in line with Hypothesis 1. Furthermore, employees are at greater risk of finding themselves unemployed or having their promotional prospects restricted when they change firm. This finding contradicts the lateral or upward interfirm job changes predicted in Hypothesis 2. In case of job exits, transitions into another employment seem to be difficult. Due to the demographic structure, we conclude that blocked promotion opportunities raise the probability of leaving a firm and, furthermore, destabilize employment trajectories.

Moreover, it has been argued that career progression prospects and employment options vary according to firm size. Results indicate that the larger the firm, the lower the rate of exits. This was especially apparent in the comparatively low unemployment risks during the cyclical decline in 2002. ${ }^{8}$ Thus, Hypothesis 3 cannot be rejected. These findings confirm that larger firms are able to strengthen the closure of their employment systems from the external job market (Struck 2006). Regarding changes from large firms during the period of economic upswing in 1999, lateral transitions between firms are particularly prominent. Those employees who change employment in the economic downturn seem restricted in their ability to increase income. Therefore, Hypothesis 4 that job exits occur mostly voluntarily and lead more frequently to lateral or even upward mobility can be confirmed only in the case of a cyclical upswing.

Turning to atypical employment, we examined the significance of fixed-term contracts ${ }^{9}$ and found that job stability declines according to the level of fixed-term employment within the firm-independent of the economic environment. In addition, unemployment risks increase after exiting a firm. This is in line with Hypothesis 5. Risks are reduced only during the cyclical periods of growth when employees can take advantage of lateral interfirm changes. To

\footnotetext{
${ }^{7}$ The dummy variable "blocked promotion opportunities" is coded with 1 when a person's position was ahead of the median of the age distribution within a firm. This is especially the case when an older age cohort is strongly represented within a firm and the own age cohort is ahead. Then, promotion opportunities for the succeeding younger cohorts should be blocked by the older cohorts. It should be noted that this modeling is aimed toward left-skewed or normally distributed age patterns, because it insufficiently captures bimodal or multimodal age distributions.

${ }^{8}$ For this purpose, the indicated coefficients are transformed into odds ratios $\exp (\beta)$ representing the delogarithmized logit coefficients. They can be expressed as probabilities $(\exp (\beta)-1) \cdot 100$.

${ }^{9}$ The intensity of use of fixed-term employees by the firms is based on their share in the entire workforce.
}

summarize, firms using a high share of fixed-term employment arrangements offer disadvantageous opportunity structures, because they increase risks in the employment trajectory (see also Grotheer et al. 2004; Struck 2006; Struck and Köhler 2004).

Hypothesis 6 assumed that firms providing further training would offer more stable jobs. This is indeed supported by our results, because employment stability is higher during cyclical up- and downswings in firms that invest in further training. Furthermore and in line with Hypothesis 7, employees who leave a firm providing further training face a comparatively low risk of unemployment and are exposed to less lateral mobility or decline. Evidently, employees working in such a firm profit from the increase in their productivity gained from the further training they have received (Büchel and Pannenberg 2004; Dieckhoff 2007) and from the positive signals ascribed to them (Backes-Gellner and Tuor 2010; Tirole 1996).

Investment in the firm's infrastructure is also taken into account. Firms with state-of-the-art technology and equipment offer high job stability during periods of growth; however, they cannot retain their employees during an economic slowdown. Therefore, Hypothesis 8 holds only during an economic upswing. Employees exiting a modern firm are comparatively well protected from downward interfirm mobility as well as from unemployment during a cyclical upswing; during an economic slowdown, they profit from lower unemployment risks. In the case of transitions between firms, they manage to maintain or even improve their income. Thus, Hypothesis 9 is especially supported in times of an economic downturn. These findings demonstrate that firms with state-of-the-art technology and equipment raise workers' productivity (Bresnahan et al. 2002) and possess a comparatively good reputation that is transferred to their employees through positive signals (Backes-Gellner and Tuor 2010; Tirole 1996).

Hypothesis 10 stated that work councils and employee representatives ensure the closure of internal employment systems and thereby increase employment stability. According to our analysis, a stabilizing effect of work councils can be observed only in a period of economic growth. During decline, personnel layoffs are still implemented even when these worker representation institutions are present. These results replicate recent studies on mobility identifying a stabilizing effect of work councils and employee representation (Boockmann and Steffes 2005, 2010; Grotheer et al. 2004). However, if the cyclical economic phases are modeled explicitly, it seems that internal closure is impossible during a cyclical downturn.

\subsection{Region-specific determinants}

This section examines how far region-specific factors correlate with employment trajectories. Hypothesis 11 predicts 
that employees who work in core areas will benefit from agglomeration advantages in terms of high job stability. This is particularly true for densely populated agglomerations in times of a cyclical upswing. In agglomerations with outstanding centers, in urbanized areas of higher density, and in urbanized areas of medium density and large regional centers, however, interfirm promotions as well as lateral changes can be realized more regularly. This confirms Hypothesis 12. During an economic downturn, support is found for Hypothesis 13, because in rural areas of lower population density, higher job instability is often accompanied by a greater risk of unemployment. Our findings indicateas stated by Fassmann and Meusburger (1997) - that urbanized areas offer more and better options for employment; in contrast, rural areas are exposed to increased unemployment risks, especially during the cyclical periods of economic decline.

To determine the significance of the local accumulation of human capital for employment trajectories, we use regional demographic data on the share of students. Hypothesis 14 states: "The higher the local level of human capital, the more stable employment will be for all workers. This stability may be realized internally or through lateral or upward interfirm mobility." Results show that regional disparities during periods of growth have only a marginal impact on employment trajectories, whereas in periods of decline, the probability of changes between firms rises in accordance with the local accumulation of human capital. Because these findings do not indicate whether or not to reject Hypothesis 14, we carried out a cross-level comparison between each of the identified qualification groups and the regional accumulation of human capital. ${ }^{10}$ Table 3 shows that the less qualified benefit from a higher local level of human capital by realizing upward or lateral interfirm mobility during an economic upturn. The same applies to those employees who have successfully completed advanced secondary education and vocational training. In contrast, those employees who have completed secondary school and vocational training have more stable employment when the local level of human capital is higher. This finding also transfers to more highly qualified employees: They are more likely to avail of the external job market for upward mobility and are in little danger of downward mobility or unemployment. This confirms Hypothesis 14 , because all qualification groups benefit from a higher regional level of human capital—as reported by Blien and Wolf (2002) and by Farhauer and Granato (2006). In comparison, during a downturn, employees with no vocational training are employed comparatively insecurely de-

\footnotetext{
${ }^{10}$ Results are taken from separate estimations that are otherwise identical to those displayed in Table 2. Likelihood ratio tests reveal that all interaction effects are highly significant.
}

spite the higher local level of human capital and are also at a higher risk of downward mobility. In an economic decline, only those employees with a secondary school and vocational training certificate profit from the higher stock of human capital to achieve interfirm promotions. This also applies to highly qualified workers who are in stable employment. The findings are in line with Hypothesis 15 and other studies (Gerlach et al. 2002; Schlitte et al. 2010; Stephan 2001) suggesting an increase in skill segregation due to a high local level of human capital. Thus, during a downturn, skill segregation exerts an unfavorable effect on low skilled employees.

\section{Conclusions}

Life course research emphasizes the significance of individual factors and endogenous causalities for employment careers; thus, the start to the employment career enduringly affects workers' future mobility patterns (Blossfeld 1986; Hillmert et al. 2004). By focusing in greater detail on structural effects this article extends current research on individual determinants of employment trajectories. Because employees act within specific contexts (Coleman 1990), this study has paid particular attention to exploring how firm characteristics and regional determinants impact on employment trajectories. It has also related these trajectories to periods of both economic growth and decline. To date, such a comprehensive survey could not be undertaken due to the lack of an adequate dataset and very long computation times.

To gain a fuller picture of structural and cyclical determinants, a German linked employer-employee dataset provided by the IAB was merged with data on regional characteristics taken from the Federal Institute for Research on Building, Urban Affairs and Spatial Development (BBSR). Regional indicators were investigated in each of the $97 \mathrm{spa}-$ tial planning regions. The data analysis was carried out in three steps. First, the frequency of exits from a firm and the consequences of these exits were explored descriptively during both a period of economic growth in 1999 and a period of economic decline in 2002. Second, the decisive factors influencing employment stability were identified and analyzed with multilevel models that permit a hierarchical clustering of the data. Third, the determinants of interfirm upward, downward, and lateral mobility as well as transitions into unemployment were considered.

At first, it could be shown that regardless of whether in a period of growth or decline, almost $10 \%$ of employees left their firm. Moreover, the identified exit states suggested a procyclical mobility of employment as well as 


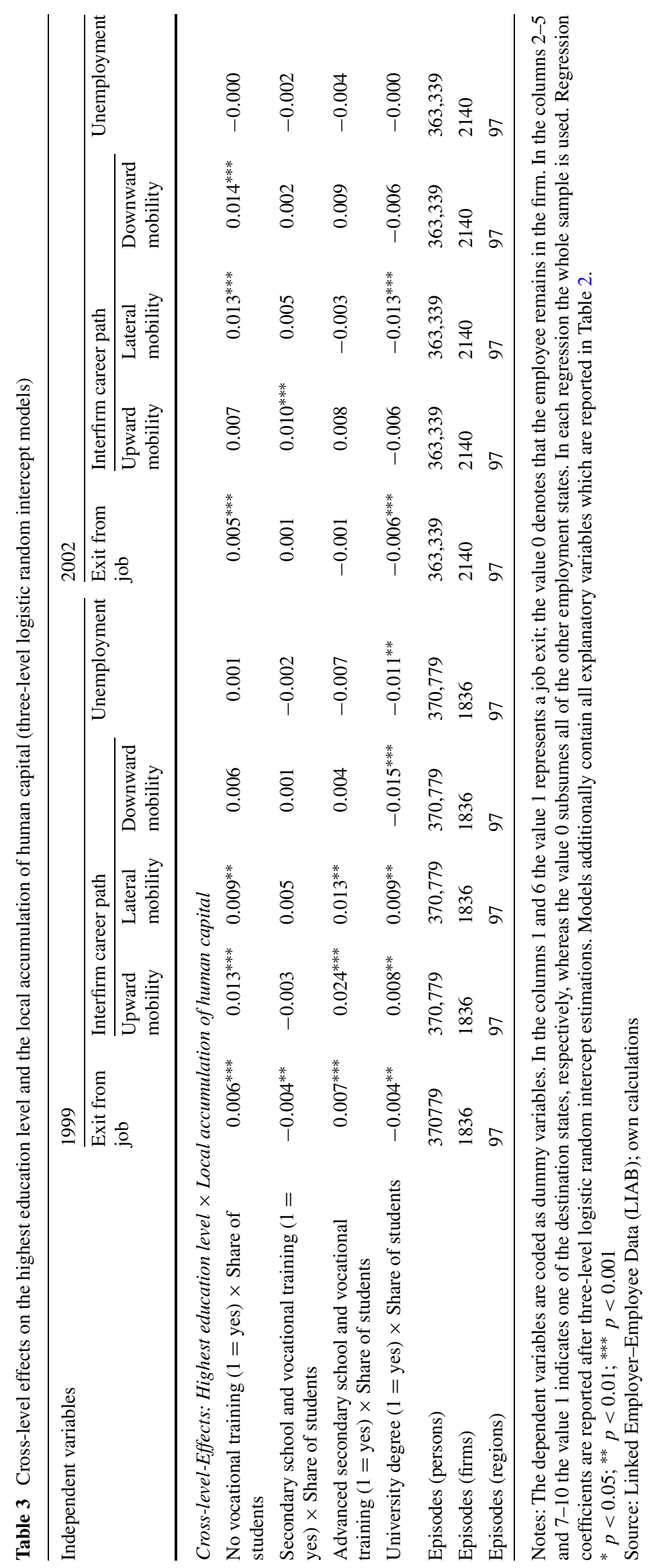


a procyclical development of wages. Thus, more interfirm promotions could be achieved during the period of economic growth than during the economic downturn. In contrast, fewer workers moved into a period of nonemployment during an economic upswing than during a decline. This information served as a backdrop for examining the significance of firm characteristics and region-specific factors.

Looking at firm-specific determinants, firm demographics correlated with processes of mobility. Thus, closed promotion opportunities destabilize employment trajectories for a part of the labor force. The multiple and diverse employment opportunities for career progression in larger firms revealed that they have more of a closed employment system. Furthermore, firms making a stronger use of fixed-term employment had very unfavorable opportunity structures, because this practice increased employment instability and the risk of unemployment. Accordingly, firms that invest in further training or their infrastructure not only improve employment opportunities but also create the conditions for interfirm mobility processes due to the positive signaling effect ascribed to their employees. Especially in a positive economic environment, work councils and employee representation increase employment stability. However, during a turn for the worse in the economy, work councils are unable to prevent dismissals.

Concerning region-specific characteristics, we analyzed the association between different settlement structures and diverse mobility patterns. Especially in periods of economic growth, more densely populated areas offer more and better employment opportunities. During periods of economic decline, in contrast, employees in rural areas face a greater risk of unemployment. Hence, the unequal employment opportunities in differently structured regions suggest a regional segmentation of the job market. Concerning the local accumulation of human capital, we found only a marginal influence on employment trajectories. It was only during an economic downturn that employees profited from a higher regional level of human capital, because transitions between firms became more frequent. A differentiation of the effect of the local level of human capital according to qualification groups revealed a two-sided story depending on the state of the economic cycle. All skill groups profit from a higher level of human capital during an economic upturn, whereas skill segregation is more apparent during a downturn.

In summary, it could be shown that employees can minimize the significant impact of individual determinants and endogenous causalities on employment careers (Blossfeld 1986; Hillmert et al. 2004) by taking advantage of good opportunity structures and framework conditions. Therefore firm characteristics and region-specific factors as well as economic conditions play an important role in career mobility patterns. This finding gains further significance particularly in light of the following three developments: First, in recent years, market volatility due to processes of economic globalization and transnationalization has been leading to ever shortening economic cycles. Second and related to this, human resource policy has changed particularly through an increased use of atypical employment contracts. Third, several political initiatives, such as the European initiative for regional development and the promotion of metropolitan regions as well as the German initiative to shift decision-making powers from the central government to local and regional units, have increased the significance of regional structures for growth and employment (Blien et al. 2001). Future research on employment careers will need to examine both structural and cyclical effects in more detail.

\section{Executive summary}

Life course research accentuates that employment trajectories are governed by individual determinants and endogenous causalities; thus, the start to the employment career enduringly affects workers' future mobility patterns. However, their actions are always embedded within a particular framework: Their employment trajectories are influenced by firmspecific opportunity structures, regional heterogeneities, and the business cycle. This article therefore extends current research on individual determinants of employment trajectories by focusing in greater detail on structural effects. To date, such a comprehensive survey could not be undertaken due to the lack of an adequate dataset and very long computation times.

To gain a fuller picture of structural and cyclical determinants, a German linked employer-employee dataset provided by the IAB is merged with data on regional characteristics taken from the Federal Institute for Research on Building, Urban Affairs and Spatial Development (BBSR). Regional indicators are investigated in each of the 97 spatial planning regions. The data analysis is carried out in three steps. First, the frequency of exits from a firm and the consequences of these exits are explored descriptively during both a period of economic growth in 1999 and a period of economic decline in 2002. Second, the decisive factors influencing employment stability are identified and analyzed with multilevel models that permit a hierarchical clustering of the data. Third, the determinants of interfirm upward, downward, and lateral mobility as well as transitions into unemployment are considered.

At first, it can be shown that regardless of whether in a period of growth or decline, almost $10 \%$ of employees 
left their firm. Moreover, the identified exit states suggest a procyclical mobility of employment as well as a procyclical development of wages. Thus, more interfirm promotions can be achieved during the period of economic growth than during the economic downturn. In contrast, fewer workers move into a period of nonemployment during an economic upswing than during a decline. This information serves as a backdrop for examining the significance of firm characteristics and region-specific factors.

Looking at firm-specific determinants, firm demographics correlate with processes of mobility. Thus, closed promotion opportunities destabilize employment trajectories for a part of the labor force. The multiple and diverse employment opportunities for career progression in larger firms reveal that they have more of a closed employment system. Furthermore, firms making a stronger use of fixed-term employment have very unfavorable opportunity structures, because this practice increases employment instability and the risk of unemployment. Accordingly, firms that invest in further training or their infrastructure not only improve employment opportunities but also create the conditions for interfirm mobility processes due to the positive signaling effect ascribed to their employees. Especially in a positive economic environment, work councils and employee representation increase employment stability. However, during a turn for the worse in the economy, work councils are unable to prevent dismissals.

Concerning region-specific characteristics, we analyze the association between different settlement structures and diverse mobility patterns. Especially in periods of economic growth, more densely populated areas offer more and better employment opportunities. During periods of economic decline, in contrast, employees in rural areas face a greater risk of unemployment. Hence, the unequal employment opportunities in differently structured regions suggest a regional segmentation of the job market. Concerning the local accumulation of human capital, we find only a marginal influence on employment trajectories. It is only during an economic downturn that employees profit from higher regional levels of human capital, because transitions between firms become more frequent. A differentiation of the effect of the local level of human capital according to qualification groups reveal a two-sided story depending on the state of the economic cycle. All skill groups profit from a higher level of human capital during an economic upturn, whereas skill segregation is more apparent during a downturn.

In summary, it can be shown that employees are able minimize the significant impact of individual determinants and endogenous causalities on employment careers by taking advantage of good opportunity structures and framework conditions. Therefore firm characteristics and region-specific factors as well as economic conditions play an important role in career mobility patterns.

\section{Kurzfassung}

In der Lebensverlaufsforschung werden die Bedeutung individueller Faktoren sowie des endogenen Kausalzusammenhangs für den Erwerbsverlauf betont. Demnach bestimmt der Einstieg in die Erwerbskarriere nachhaltig das zukünftige Mobilitätsverhalten der Beschäftigten. Allerdings agieren diese immer auch innerhalb spezifischer Rahmenbedingungen. Erwerbsverläufe werden durch firmenspezifische Gelegenheitsstrukturen, regionale Heterogenitäten und die jeweilige konjunkturelle Situation beeinflusst. Vor diesem Hintergrund erweitert dieser Beitrag die aktuelle Forschung zu den individuellen Determinanten von Erwerbsverläufen, indem der Fokus auf strukturelle Faktoren gerichtet wird. Solche Analysen konnten bislang aufgrund des Fehlens adäquater Daten und sehr langer Rechenzeiten nicht durchgeführt werden.

Um ein umfassendes Bild der strukturellen und konjunkturellen Faktoren zu erhalten, wird ein deutscher LinkedEmployer-Employee Datensatz des Instituts für Arbeitsmarkt- und Berufsforschung (IAB) mit Informationen zu regionalen Charakteristika aus dem Bundesinstitut für Bau-, Stadt- und Raumforschung (BBSR) verknüpft. Die regionalen Indikatoren werden auf der Ebene der 97 Raumordnungsregionen untersucht. Die Datenanalyse erfolgt in drei Schritten. Zunächst werden deskriptiv die Anzahl der Austritte von Beschäftigten aus Betrieben sowie die anschließenden Arbeitsmarktstatus sowohl in der konjunkturellen Aufschwungphase im Jahr 1999 als auch in der Abschwungphase im Jahr 2002 betrachtet. Zweitens werden die Einflussfaktoren auf die Beschäftigungsstabilität anhand von Mehrebenenmodellen, welche die hierarchische Clusterung der Daten berücksichtigen, analysiert. Drittens werden ebenfalls multivariat die Determinanten von Aufstiegen, lateraler Mobilität und Abstiegen bei direkten Betriebswechseln sowie von Übergängen in Arbeitslosigkeit erforscht.

Zunächst kann gezeigt werden, dass unabhängig von der konjunkturellen Situation ca. $10 \%$ der Beschäftigten ihren Betrieb verlassen haben. Zudem verdeutlichen die anschließenden Arbeitsmarktstatus eine prozyklische Beschäftigungsmobilität sowie eine prozyklische Entwicklung der Löhne. So liegt eine höhere zwischenbetriebliche Mobilität während des wirtschaftlichen Aufschwungs im Vergleich zur Situation während des Abschwungs vor. Hingegen gibt es weniger Übergänge in eine Phase der Nichtbeschäftigung im wirtschaftlichen Aufschwung. Diese Informationen dienen als Ausgangsbefunde für die Untersuchung des Einflusses betrieblicher Charakteristika und regionaler Disparitäten auf individuelle Erwerbsverläufe.

Hinsichtlich der firmenspezifischen Determinanten besitzt die Betriebsdemografie eine Bedeutung für Mobilitäts- 
prozesse. Demnach destabilisieren versperrte Aufstiegswege die Erwerbsverläufe eines Teils der Belegschaft. Größere Betriebe weisen aufgrund der vielfältigeren Beschäftigungsmöglichkeiten stärker geschlossene Beschäftigungssysteme auf. Darüber hinaus bieten Betriebe, die in größerem Umfang befristete Arbeitsverträge einsetzen, ungünstige Gelegenheitsstrukturen, da durch diese Praxis die Beschäftigungsinstabilität sowie das Arbeitslosigkeitsrisiko steigen. Hingegen erhöhen Betriebe, die in die Weiterbildung ihrer Arbeitskräfte oder in ihre Infrastruktur investieren, nicht nur die Beschäftigungsstabilität, sondern ermöglichen auch adäquate zwischenbetriebliche Mobilitätsprozesse aufgrund von positiven Signalen, die ihren Beschäftigten zugeschrieben werden. Vor allem während einer guten konjunkturellen Situation erhöhen Betriebsräte und Arbeitnehmervertretungen die Beschäftigungsstabilität. Allerdings sind Betriebsräte während eines konjunkturellen Abschwungs nicht mehr in der Lage, Entlassungen zu verhindern.

Mit Blick auf regionsspezifische Charakteristika werden zunächst der Zusammenhang zwischen verschiedenen Siedlungsstrukturen und der Beschäftigungsmobilität analysiert. Insbesondere während eines konjunkturellen Aufschwungs bieten dichter besiedelte Gebiete mehr und bessere Beschäftigungsmöglichkeiten. In Zeiten des konjunkturellen Abschwungs sind die Beschäftigten in ländlichen Gebieten hingegen einem größeren Arbeitslosigkeitsrisiko ausgesetzt. Folglich deuten die ungleichen Beschäftigungsmöglichkeiten in den unterschiedlich strukturierten Regionen auf eine regionale Segmentierung des Arbeitsmarktes hin. Bezüglich der regionalen Humankapitalausstattung finden wir nur einen geringen Einfluss auf Erwerbsverläufe vor. Le- diglich während des wirtschaftlichen Abschwungs profitieren die Beschäftigten von einer höheren regionalen $\mathrm{Hu}$ mankapitalausstattung, da zwischenbetriebliche Übergänge häufiger auftreten. Eine weitere Differenzierung der Wirkung der regionalen Humankapitalausstattung nach Qualifikationsgruppen ergibt in Abhängigkeit von der konjunkturellen Situation ein zweigeteiltes Bild. Von einer hohen regionalen Humankapitalausstattung profitieren im Aufschwung alle Qualifikationsgruppen, während im Abschwung eine Segregation bezüglich der Qualifikationsgruppen zu beobachten ist.

Zusammenfassend zeigen die Befunde, dass die zweifellos vorhandenen endogenen Kausalzusammenhänge im Erwerbsverlauf dann an Bedeutung verlieren, wenn Beschäftigte sich strukturelle Einflussfaktoren zunutze machen können. Aus diesem Grund besitzen betriebliche Charakteristika und regionale Disparitäten sowie die konjunkturellen Rahmenbedingungen mit Blick auf Erwerbsverläufe eine hohe Relevanz.

Acknowledgements We would like to thank Ute Leber and two anonymous referees for very helpful comments and suggestions. We also appreciate comments received from participants of the User Conference of the IAB Establishment Panel Survey in October 2012.

\section{Appendix}

See Tables 4-8.
Table 4 Description of the dependent variables
Source: Linked Employer-Employee Data (LIAB); own calculations

\begin{tabular}{|c|c|c|c|}
\hline \multirow[t]{2}{*}{ Variable } & \multicolumn{2}{|l|}{ Mean } & \multirow[t]{2}{*}{ Description } \\
\hline & 1999 & 2002 & \\
\hline Exit from job & 0.092 & 0.083 & $\begin{array}{l}\text { Dummy }=1 \text { if employee leaves the firm; Dummy }=0 \text { if } \\
\text { employee remains in firm }\end{array}$ \\
\hline $\begin{array}{l}\text { Interfirm upward } \\
\text { mobility }\end{array}$ & 0.018 & 0.011 & $\begin{array}{l}\text { Dummy }=1 \text { if interfirm upward mobility takes place; } \\
\text { Dummy }=0 \text { if another employment status is observed }\end{array}$ \\
\hline $\begin{array}{l}\text { Interfirm lateral } \\
\text { mobility }\end{array}$ & 0.014 & 0.012 & $\begin{array}{l}\text { Dummy }=1 \text { if interfirm lateral mobility takes place; } \\
\text { Dummy }=0 \text { if another employment status is observed }\end{array}$ \\
\hline $\begin{array}{l}\text { Interfirm downward } \\
\text { mobility }\end{array}$ & 0.009 & 0.008 & $\begin{array}{l}\text { Dummy }=1 \text { if interfirm downward mobility takes place; } \\
\text { Dummy }=0 \text { if another employment status is observed }\end{array}$ \\
\hline Unemployment & 0.024 & 0.025 & $\begin{array}{l}\text { Dummy }=1 \text { if employee becomes unemployed; Dummy } \\
=0 \text { if another employment status is observed }\end{array}$ \\
\hline $\begin{array}{l}\text { Number of } \\
\text { observations }\end{array}$ & 370,779 & 363,339 & \\
\hline
\end{tabular}


Table 5 Description of individual characteristics
${ }^{1}$ Percentages do not add up to exactly 100 due to imprecise rounding off.

Source: Linked

Employer-Employee Data

(LIAB); own calculations

Table 6 Description of firm-specific characteristics

\footnotetext{
${ }^{1}$ Percentages do not add up to exactly 100 due to imprecise rounding off.

2 " 1 " indicates that the establishment has state-of-the-art equipment; " 5 " indicates that the equipment is obsolete.

Source: Linked

Employer-Employee Data (LIAB); own calculations
}

\begin{tabular}{|c|c|c|c|c|}
\hline \multirow[t]{2}{*}{ Characteristics } & \multicolumn{2}{|l|}{1999} & \multicolumn{2}{|l|}{2002} \\
\hline & Mean & Standard Deviation & Mean & Standard Deviation \\
\hline $\operatorname{Sex}(1=$ female $)$ & 28.87 & 0.45 & 27.00 & 0.44 \\
\hline Nationality $(1=$ foreign $)$ & 7.39 & 0.26 & 7.92 & 0.27 \\
\hline \multicolumn{5}{|l|}{ Age in years 1} \\
\hline $25-34$ & 32.05 & $-1-$ & 27.53 & $-1-$ \\
\hline $35-44$ & 41.06 & $-1-$ & 43.45 & $-1-$ \\
\hline $45-52$ & 26.89 & $-1-$ & 29.01 & $-1-$ \\
\hline \multicolumn{5}{|l|}{ Highest education level $^{1}$} \\
\hline No vocational training & 12.24 & $-1-$ & 11.91 & $-1-$ \\
\hline $\begin{array}{l}\text { Secondary school and vocational } \\
\text { training }\end{array}$ & 71.03 & $-1-$ & 68.99 & $-1-$ \\
\hline $\begin{array}{l}\text { Advanced secondary school and } \\
\text { vocational training }\end{array}$ & 4.01 & $-1-$ & 5.46 & $-1-$ \\
\hline University degree & 12.71 & $-1-$ & 13.63 & $-1-$ \\
\hline \multicolumn{5}{|l|}{ Job position ${ }^{1}$} \\
\hline Unskilled blue-collar & 25.68 & $-1-$ & 24.20 & $-1-$ \\
\hline Skilled blue-collar & 29.19 & $-1-$ & 29.87 & $-1-$ \\
\hline Master craftsman & 1.71 & $-1-$ & 1.65 & $-1-$ \\
\hline White-collar & 43.42 & $-1-$ & 44.29 & $-1-$ \\
\hline \multicolumn{5}{|l|}{ Previous employment state ${ }^{1}$} \\
\hline Share of employment & 0.32 & $-1-$ & 0.33 & $-l-$ \\
\hline Share of unemployment & 0.05 & $-1-$ & 0.04 & $-1-$ \\
\hline Share of nonemployment & 0.07 & $-1-$ & 0.08 & $-l-$ \\
\hline First employment & 0.03 & $-1-$ & 0.02 & $-1-$ \\
\hline $\begin{array}{l}\text { Permanently employed } \\
\text { Cohorts }^{1}\end{array}$ & 0.53 & $-1-$ & 0.53 & $-l-$ \\
\hline Entrance at most 1 year ago & 16.99 & $-1-$ & 16.07 & $-1-$ \\
\hline Entrance $1-5$ years ago & 25.00 & $-1-$ & 27.10 & $-1-$ \\
\hline Entrance more than 5 years ago & 58.01 & $-1-$ & 56.82 & $-1-$ \\
\hline Number of observations & 370,779 & & 363,339 & \\
\hline \multirow[t]{2}{*}{ Characteristics } & \multicolumn{2}{|l|}{1999} & \multicolumn{2}{|l|}{2002} \\
\hline & Mean & Standard Deviation & Mean & Standard Deviation \\
\hline \multicolumn{5}{|l|}{ Firm size ${ }^{1}$} \\
\hline Small firm & 25.05 & $-1-$ & 26.17 & $-1-$ \\
\hline Small-medium-sized firm & 45.21 & $-1-$ & 46.31 & $-1-$ \\
\hline Medium-sized firm & 14.22 & $-1-$ & 14.39 & $-1-$ \\
\hline Larger firm & 15.52 & $-1-$ & 13.13 & $-1-$ \\
\hline \multicolumn{5}{|l|}{ Qualification structure $^{1}$} \\
\hline Simple tasks & 0.18 & $-1-$ & 0.19 & $-1-$ \\
\hline Qualified tasks & 0.83 & $-1-$ & 0.81 & $-1-$ \\
\hline Share of fixed-term employees & 0.05 & $-1-$ & 0.04 & $-1-$ \\
\hline Investments in further training & 76.85 & $-1-$ & 76.64 & $-1-$ \\
\hline $\begin{array}{l}\text { Technological state of machinery } \\
\text { and equipment }{ }^{2}\end{array}$ & 2.92 & $-1-$ & 2.84 & $-1-$ \\
\hline Works council $(1=$ yes $)$ & 50.11 & 0.50 & 49.91 & 0.50 \\
\hline \multicolumn{5}{|l|}{ Sector ${ }^{1}$} \\
\hline Agriculture, forestry, and mining & 4.74 & $-1-$ & 4.11 & $-1-$ \\
\hline Construction & 15.41 & $-1-$ & 12.06 & $-1-$ \\
\hline Manufacturing industry & 33.71 & $-1-$ & 39.44 & $-1-$ \\
\hline Trade & 12.53 & $-1-$ & 12.29 & $-1-$ \\
\hline Services for firms & 6.48 & $-1-$ & 7.24 & $-l-$ \\
\hline Other services & 21.79 & $-1-$ & 19.95 & $-1-$ \\
\hline Number of observations & 1,836 & & 2,140 & \\
\hline
\end{tabular}


Table 7 Description of the regional distribution of employment-relevant factors

${ }^{1}$ Percentages do not add up to exactly 100 due to imprecise rounding off.

Source: Linked

Employer-Employee Data

(LIAB); own calculations

\begin{tabular}{|c|c|c|c|c|}
\hline \multirow[t]{2}{*}{ Characteristics } & \multicolumn{2}{|l|}{1999} & \multicolumn{2}{|l|}{2002} \\
\hline & Mean & Standard Deviation & Mean & Standard Deviation \\
\hline \multicolumn{5}{|l|}{ Types of region ${ }^{1}$} \\
\hline $\begin{array}{l}\text { Densely populated } \\
\text { agglomerations }\end{array}$ & 24.36 & $-1-$ & 24.36 & $-1-$ \\
\hline $\begin{array}{l}\text { Agglomerations with outstanding } \\
\text { centers }\end{array}$ & 23.55 & $-1-$ & 23.55 & $-1-$ \\
\hline $\begin{array}{l}\text { Urbanized areas of higher } \\
\text { density }\end{array}$ & 14.58 & $-1-$ & 14.58 & $-1-$ \\
\hline $\begin{array}{l}\text { Urbanized areas of medium } \\
\text { density and large regional centers }\end{array}$ & 17.96 & $-1-$ & 17.96 & $-1-$ \\
\hline $\begin{array}{l}\text { Urbanized areas of medium } \\
\text { density without large regional } \\
\text { centers }\end{array}$ & 2.84 & $-1-$ & 2.84 & $-1-$ \\
\hline Rural areas of higher density & 12.18 & $-1-$ & 12.18 & $-1-$ \\
\hline Rural areas of lower density & 4.53 & $-1-$ & 4.53 & $-/-$ \\
\hline Share of students & 47.57 & 13.76 & 19.69 & 14.46 \\
\hline Unemployment rate & 11.77 & 4.67 & 11.08 & 5.21 \\
\hline GDP (per capita) & 22.63 & 5.33 & 24.00 & 5.66 \\
\hline Number of observations & 97 & & 97 & \\
\hline
\end{tabular}

Table 8 Estimation results for intercept-only models (three-level logistic random intercept models without explanatory variables)

\begin{tabular}{|c|c|c|c|c|c|c|c|c|c|c|}
\hline \multirow{3}{*}{$\begin{array}{l}\text { Independent } \\
\text { variables }\end{array}$} & \multicolumn{5}{|l|}{1999} & \multicolumn{5}{|l|}{2002} \\
\hline & \multirow{2}{*}{$\begin{array}{l}\text { Exit } \\
\text { from job }\end{array}$} & \multicolumn{3}{|c|}{ Interfirm career path } & \multirow[t]{2}{*}{ Unemployment } & \multirow{2}{*}{$\begin{array}{l}\text { Exit } \\
\text { from job }\end{array}$} & \multicolumn{3}{|c|}{ Interfirm career path } & \multirow[t]{2}{*}{ Unemployment } \\
\hline & & $\begin{array}{l}\text { Upward } \\
\text { mobility }\end{array}$ & $\begin{array}{l}\text { Lateral } \\
\text { mobility }\end{array}$ & $\begin{array}{l}\text { Downward } \\
\text { mobility }\end{array}$ & & & $\begin{array}{l}\text { Upward } \\
\text { mobility }\end{array}$ & $\begin{array}{l}\text { Lateral } \\
\text { mobility }\end{array}$ & $\begin{array}{l}\text { Downward } \\
\text { mobility }\end{array}$ & \\
\hline $\begin{array}{l}\text { Residual variance } \\
\text { (persons) }\end{array}$ & 3.290 & 3.290 & 3.290 & 3.290 & 3.290 & 3.290 & 3.290 & 3.290 & 3.290 & 3.290 \\
\hline $\begin{array}{l}\text { Residual variance } \\
\text { (firms) }\end{array}$ & 1.036 & 1.665 & 2.291 & 1.433 & 0.787 & 1.534 & 2.209 & 3.005 & 1.751 & 1.946 \\
\hline $\begin{array}{l}\text { Residual variance } \\
\text { (regions) }\end{array}$ & 0.051 & 0.033 & 0.052 & 0.042 & 0.046 & 0.053 & 0.045 & 0.062 & 0.049 & 0.053 \\
\hline $\begin{array}{l}\text { Intrafirm correlation } \\
(\rho(\text { firm, region }))\end{array}$ & 0.248 & 0.340 & 0.416 & 0.310 & 0.202 & 0.325 & 0.407 & 0.482 & 0.354 & 0.378 \\
\hline $\begin{array}{l}\text { Intraregion } \\
\text { correlation } \\
(\rho(\text { region }))\end{array}$ & 0.011 & 0.010 & 0.010 & 0.010 & 0.011 & 0.011 & 0.010 & 0.010 & 0.010 & 0.010 \\
\hline Episodes (persons) & 370,779 & 370,779 & 370,779 & 370,779 & 370,779 & 363,339 & 363,339 & 363,339 & 363,339 & 363,339 \\
\hline Episodes (firms) & 1,836 & 1,836 & 1,836 & 1,836 & 1,836 & 2,140 & 2,140 & 2,140 & 2,140 & 2,140 \\
\hline Episodes (regions) & 97 & 97 & 97 & 97 & 97 & 97 & 97 & 97 & 97 & 97 \\
\hline
\end{tabular}

Notes: The dependent variables are coded as dummy variables. In the columns 1 and 6 the value 1 represents a job exit; the value 0 denotes, when the employee remains in the firm. In the columns $2-5$ and 7-10 the value 1 indicates one of the destination states, respectively, whereas the value 0 subsumes all of the other employment states. In each regression the whole sample is used.

Source: Linked Employer-Employee Data (LIAB); own calculations

\section{References}

Ahrne, G.: Social Organizations. Interaction Inside, Outside and Between Organizations. Sage, London (1994)

Alewell, D., Hansen, N.K.: Human resource management systemsa structured review of research contributions and open questions. Ind. Bezieh. 19, 90-123 (2012)
Backes-Gellner, U., Tuor, S.: Avoiding labor shortages by employer signaling: on the importance of good work climate and labor relations. Ind. Labor Relat. Rev. 63, 271-286 (2010)

Baron, J., Bielby, W.: Bringing the firms back in: stratification, segmentation, and the organization of work. Am. Sociol. Rev. 45, 737-765 (1980)

Becker, G.: Investment in human capital: a theoretical analysis. J. Polit. Econ. 70, 9-42 (1962) 
Bergemann, A., Mertens, A.J.: Stability trends, layoffs, and transitions to unemployment: an empirical analysis for West Germany. IZA Discussion Paper 1368 (2004)

Blien, U.: Arbeitslosigkeit und Entlohnung auf regionalen Arbeitsmärkten. Theoretische Analyse, ökonometrische Methode, empirische Evidenz und wirtschaftspolitische Schlussfolgerungen für die Bundesrepublik Deutschland. Physica, Heidelberg (2001)

Blien, U., Wolf, K.: Regional development of employment in Eastern Germany: an analysis with an econometric analogue to shift-share techniques. Pap. Reg. Sci. 81, 391-414 (2002)

Blien, U., Haas, A., Hirschenauer, F., Maierhofer, E., Tassinopoulos, A., Vollkommer, D., Wolf, K.: Regionale Arbeitsmarktforschung im IAB. Mitt. Arb.markt- Berufsforsch. 34, 45-73 (2001)

Blossfeld, H.-P.: Career opportunities in the Federal Republic of Germany: a dynamic approach to the study of life-course, cohort, and period effects. Eur. Sociol. Rev. 3, 208-225 (1986)

Blossfeld, H.-P., Klijzing, E., Mills, M., Kurz, K.: Globalization, Uncertainty and Youth in Society. Routledge, London (2005)

Blossfeld, H.-P., Mills, M., Bernardi, F.: Globalization, Uncertainty and Men's Careers: An International Comparison. Elgar, Cheltenham (2006)

Boockmann, B., Steffes, S.: Individual and plant-level determinants of job durations in Germany. ZEW-Discussion Paper 89 (2005)

Boockmann, B., Steffes, S.: Workers, firms or institutions: what determines job duration for male employees in Germany? Ind. Labor Relat. Rev. 64, 109-127 (2010)

Bresnahan, T.F., Brynjolfsson, E., Hitt, L.M.: Information technology, workplace organization and the demand for skilled labor: firmlevel evidence. Q. J. Econ. 117, 339-376 (2002)

Büchel, F., Pannenberg, M.: Berufliche Weiterbildung in West- und Ostdeutschland-Teilnehmer, Struktur und individueller Ertrag. Z. Arb.markt Forsch. 2, 73-126 (2004)

Carroll, G.R., Mayer, K.U.: Job-shift patterns in the Federal Republic of Germany: the effects of social class, industrial sector, and organizational size. Am. Sociol. Rev. 51(3), 323-341 (1986)

Coleman, J.S.: Foundations of Social Theory. Belknap Press of Harvard University Press, Cambridge (1990)

Devereux, P., Hart, R.: Real wage cyclicality of job stayers, withincompany job movers, and between-company job movers. Ind. Labor Relat. Rev. 60, 105-119 (2006)

Dieckhoff, M.: Does it work? The effect of continuing training on labour market outcomes: a comparative study of Germany, Denmark, and the United Kingdom. Eur. Sociol. Rev. 3, 295-308 (2007)

Doeringer, P., Piore, M.: Internal Labor Markets and Manpower Analysis. D.C. Heath, Lexington (1971)

Erlinghagen, M.: Entlassungen und Beschäftigungssicherheit im Zeitverlauf. Zur Entwicklung unfreiwilliger Arbeitsmarktmobilität in Deutschland. Z. Soziol. 34, 147-168 (2005)

Farhauer, O., Granato, N.: Regionale Arbeitsmärkte in Westdeutschland: Standortfaktoren und Branchenmix entscheidend für Beschäftigung. IAB-Kurzbericht 4 (2006)

Fassmann, H., Meusburger, P.: Arbeitsmarktgeographie. Erwerbstätigkeit und Arbeitslosigkeit im räumlichen Kontext. Teubner, Stuttgart (1997)

Fischer, G., Janik, F., Müller, D., Schmucker, A.: Das IABBetriebspanel-von der Stichprobe über die Erhebung bis zur Hochrechnung. FDZ-Methodenreport 1 (2008)

Fitzenberger, B., Garloff, A.: Labor market transitions and the wage structure in Germany. Jahrb. Natl.ökon. Stat. 227(2), 115-152 (2007)

Fitzenberger, B., Osikominu, A., Völter, R.: Imputation rules to improve the education variable in the IAB employment subsample. FDZ-Methodenreport 3 (2005)

Fujita, M., Krugman, P., Venables, A.: The Spatial Economy. Cities, Regions and International Trade. MIT Press, Cambridge (2001)
Gerlach, K., Meyer, W., Tsertsvadze, G.: Entwicklung der qualifikatorischen Segregation im Verarbeitenden Gewerbe. In: Bellmann, L., Kölling, A. (eds.) Betrieblicher Wandel und Fachkräftebedarf, pp. 51-84. Institut für Arbeitsmarkt- und Berufsforschung, Nürnberg (2002)

Giesecke, J., Heisig, J.P.: Destabilization and destandardization: for whom? The development of West German job mobility since 1984. Z. Wirtsch.- Sozialwiss. 131(2), 301-314 (2011)

Grotheer, M., Struck, O., Bellmann, L., Gewiese, T.: Determinanten der Beschäftigungsstabilität. Chancen und Risiken von „Entrants“ im Ost-West-Vergleich. In: Struck, O., Köhler, C. (eds.) Beschäftigungsstabilität im Wandel? Empirische Befunde und theoretische Erklärungen für Ost- und Westdeutschland, pp. 181-198. Rainer Hampp, Mering (2004)

Hart, R.: Worker-job matches, job mobility and real wage cyclicality. Economica 73, 287-298 (2006)

Heinz, W.: From work trajectories to negotiated careers: the contingent work life course. In: Mortimer, J.T., Shanahan, M.J. (eds.) Handbook of the Life Course, pp. 185-204. Springer, New York (2006)

Hendry, C.: Applying employment systems theory to the analysis of national models of HRM. Int. J. Hum. Resour. Manag. 14, 14301442 (2003)

Hillmert, S., Kurz, K., Grunow, D.: Beschäftigungsstabilität in der ersten Hälfte des Erwerbslebens. Ein Kohortenvergleich. In: Struck, O., Köhler, C. (eds.) Beschäftigungsstabilität im Wandel? pp. 6386. Rainer Hampp, Mering (2004)

Hinz, T., Abraham, M.: Theorien des Arbeitsmarktes: Ein Überblick. In: Abraham, M., Hinz, T. (eds.) Arbeitsmarktsoziologie. Probleme, Theorien, empirische Befunde, pp. 17-68. VS-Verlag, Wiesbaden (2008)

Hirschman, A.: The Strategy of Economic Development. Yale University Press, New Haven (1958)

Hohendanner, C.: Unsichere Zeiten, unsichere Verträge? IAB Kurzbericht 14 (2010)

Hübler, O., Walter, T.: Beschäftigungsstabilität im Konjunkturzyklus-Eine empirische Analyse mit Individualdaten für Westdeutschland 1984-2005. Z. Wirtsch.- Sozialwiss. 129, 1-35 (2009)

Jacobebbinghaus, P.: LIAB-Datenhandbuch. Version 3.0. FDZDatenreport 3 (2008)

Jirjahn, U.: The introduction of works councils in German establishments-rent seeking or rent protection? Br. J. Ind. Relat. 3, 521-545 (2009)

Krugman, P.: Geography and Trade. MIT Press, Cambridge (1991)

Krugman, P.: What's new about the new economic geography? Oxf. Rev. Econ. Policy 14, 7-17 (1998)

Lepak, D.P., Liao, H., Chung, Y., Harden, E.E.: A conceptual review of human resource management systems in strategic human resource management research. Res. Pers. Hum. Resour. Manag. 25, 217 271 (2006)

Lucas, R.: On the mechanics of economic development. J. Monet. Econ. 22, 3-42 (1988)

Mittman, B.: Theoretical and methodological issues in the study of organizational demography and demographic change. In: Tolbert, P., Bacharach, S.B. (eds.) Research in the Sociology of Organizations, vol. 10, pp. 3-53. Greenwich, London (1992)

Mohrenweiser, J., Marginson, P., Backes-Gellner, U.: What triggers the establishment of a works council? Econ. Ind. Democr. 2, 295-316 (2012)

Möller, J., Tassinopoulos, A.: Zunehmende Spezialisierung oder Strukturkonvergenz? Eine Analyse der sektoralen Beschäftigungsentwicklung auf regionaler Ebene. Jahrb. Reg. wiss. 20, 1-38 (2000)

Moulton, B.: Random group effects and the precision of regression estimates. J. Econom. 32, 385-397 (1986) 
Moulton, B.: An illustration of a pitfall in estimating the effects of aggregate variables on micro units. Rev. Econ. Stat. 72, 334-338 (1990)

Neubäumer, R.: Warum bilden Betriebe ihre Mitarbeiter weiteroder auch nicht? Ein theoretischer Ansatz zur Erklärung unterschiedlicher Weiterbildungsaktivitäten von Betrieben. In: Weiß, M. (ed.) Evidenzbasierte Bildungspolitik: Beiträge der Bildungsökonomie, pp. 93-113. Duncker \& Humblot, Berlin (2006)

Pfeffer, J.: Organizational demography: implications for management. Calif. Manag. Rev. 28, 67-81 (1985)

Pfeifer, C.: Works councils, union bargaining and quits in German firms. Econ. Ind. Democr. 32(2), 243-260 (2011)

Rabe-Hesketh, S., Skrondal, A.: Multilevel and Longitudinal Modeling Using Stata. Stata Press, College Station (2008)

Rendtel, U., Schwarze, J.: Schätzungen von Lohnkurven für Westdeutschland mit einem verallgemeinerten Varianz-KomponentenModell. Mitt. Arb.markt- Berufsforsch. 3, 491-493 (1996)

Sachverständigenrat zur Begutachtung der gesamtwirtschaftlichen Entwicklung: Jahresgutachten 2008/09 „Finanzkrise meisternWachstumskräfte stärken“. Statistisches Bundesamt, Wiesbaden (2008)

Sachverständigenrat zur Begutachtung der gesamtwirtschaftlichen Entwicklung: Jahresgutachten 2009/10 „Die Zukunft nicht aufs Spiel setzen“. Statistisches Bundesamt, Wiesbaden (2009)

Schaffner, S.: Heterogeneity in the cyclical sensitivity of job-to-job flows. Z. Arb.markt Forsch. 43, 263-275 (2011)

Schlitte, F., Böttcher, F., Niebuhr, A., Diez, J.: The determinants of regional disparities in skill segregation-evidence from a cross section of German regions. HWWI Research Paper 1-36 (2010)

Schwarze, J.: Neue Befunde zur „Lohnkurve“ in Deutschland: Eine Analyse mit Paneldaten für Raumordnungsregionen 1985 und 1989. DIW Diskussionspapier 119 (1995)

Sengenberger, W.: Struktur und Funktionsweise von Arbeitsmärkten. Die Bundesrepublik Deutschland im internationalen Vergleich. Campus, Frankfurt a.M. (1987)

Skrondal, A., Rabe-Hesketh, S.: Multilevel logistic regression for polytomous data and rankings. Psychometrika 68, 267-287 (2003)

Sørensen, A.: The structure of inequality and the process of attainment. Am. J. Sociol. 101, 965-978 (1977)
Stephan, G.: Firmenlohndifferenziale. Eine Analyse für die Bundesrepublik Deutschland. Campus, Frankfurt a.M. (2001)

Struck, O., Dütsch, M.: Gesicherte Mobilität am Arbeitsmarkt. Zur Bedeutung berufsfachlicher Qualifikationen in geschlossenen und offenen Beschäftigungssystemen. Ind. Bezieh. 19(2), 124-153 (2012)

Struck, O., Grotheer, M., Schröder, T., Köhler, C.: Instabile Beschäftigung. Neue Ergebnisse zu einer alten Kontroverse. Köln. Z. Soziol. Soz.psychol. 59, 294-317 (2007)

Struck, O., Köhler, C.: Beschäftigungsstabilität im Wandel? Rainer Hampp, Mering (2004)

Struck, O.: Flexibilität und Sicherheit. Empirische Befunde, theoretische Konzepte und institutionelle Gestaltung von Beschäftigungsstabilität. VS-Verlag, Wiesbaden (2006)

Tirole, J.: A theory of collective reputations (with applications to the persistence of corruption and to firm quality). Rev. Econ. Stud. 63(1), 1-22 (1996)

Vobruba, G.: Alternativen zur Vollbeschäftigung. Suhrkamp, Frankfurt a.M. (2000)

Winkelmann, R., Zimmermann, K.: Is job stability declining in Germany? Evidence from count data models. Appl. Econ. 30, 14131420 (1998)

Matthias Dütsch studied Social Sciences at the University of ErlangenNuremberg. Since 2009 he is a research assistant at the Chair of Labor Studies at the Otto-Friedrich-University of Bamberg. His research interests focuses on atypical employment, employment systems and labor mobility.

Prof. Dr. Olaf Struck is Professor of Labor Studies at the OttoFriedrich-University of Bamberg. He is head of the Pillar 2 "Learning Environments" in the National Education Panel Study (NEPS) and head of Pillar 3 "Changes in Human Capital, Labour Markets and Demographic Structures and their Impact on Social Inequality in Modern Societies" in the Bamberg Graduate School of Social Sciences (BAGSS). Furthermore, he is on the board of the "German Association for Labour Market Research". Research interests: empirical labor market research, human resource management, further education and lifelong learning. 